\title{
Land resource assessment for agricultural development in Seoni district (Madhya Pradesh), India
}

\author{
B. P. Bhaskar*, S. G. Anantwar, S. S. Gaikwad and S. V. Bobade
}

Division of Soil Resource Studies, National Bureau of Soil Survey and Land Use Planning, Amravati Road, Nagpur440010 (Maharashtra), INDIA

*Corresponding author. E-mail: bhaskar_phaneendra@yahoo.co.in

Received: June 6, 2015; Revised received: February 22, 2016; Accepted: May 10, 2016

Abstract: The objective of land resource assessment for rainfed agridevelopment in tribal dominated Seoni ditrict, Madhya Pradesh was to assess the suitability of thrity soil mapping units for sorghum-cotton based systems in relation to fertility constraints and for enhancing crop productivity. The arability and suitability analysis showed that fifty six per cent of arable land is suitable for eleven land use systems. The twenty two per cent of arable basaltic lands in northen plateaus were evaluated as suitable for for citrus, sorghum and soybean cropping systems with limitations of low available nitrogen, phosphorus and zinc whereas in southern precipitous zone, fifteen per cent of granitic lands were evaluated as suitable for sorghum and cotton with limitations of stoniness, low water holding capacity, low status of available nitrogen, phosphorus, potassium and zinc and eighteen per cent of area in sagar and hirvi river valleys for rice, citrus, maize, sunflower and vegetables. Out of 44.6 per cent of nonarable land, thirty seven per cent of land was evaluated as suitable for forestry / grazing and 6.8 per cent for wild life.The study advocates agroecological zonation for maximum utilization of land resources for potential cropping systems in improving produvtivity and fertility management.

Keywords: Basaltic clay soils, Geographical information system (GIS), Land evaluation, Seoni, Soil survey

\section{INTRODUCTION}

The land resource inventory brings together the layered information on physical environment and allows the creation of unique mapping units within which landform, soil and climatic conditions are quantified and considered relatively homogenous (Zinck, 1998). The soil survey reports were used to produce both agricultural and urban land use plans. The use of ARC/INFO Geographical information system (GIS) (Arc is supposed to represent the smallest element of a vector data (or line), INFO was the name of the database management tool) tool for digitization of soil survey reports and maps, creating data bases of soil information and linking digital data bases and maps for regional planning in land evaluation programmes (Kushwaha et al., 1996, Maji et al., 2001, Ritung et al., 2007, Bobade et al. 2010, Rabia, 2012 and Bhaskar et al., 2014). Soil survey and mapping produces a primary data set indicating the range of soils that are encountered, their distribution, and their relative importance. From soil surveys, the profile characteristics can be interpreted to assess a range of the limiting factors that relate to land preparation, crop establishment, and crop growth. Indeed the default source of information for limiting factors is the soil survey and the typical properties described for each soil. Soil chemical and physical (and biological) properties should be determined in addition, wherever possible, for a number of land qualities, but in their absence, proxy values are used from soil survey information. For example, $\mathrm{P}$ retention can be determined as a relatively definitive value from a soil chemical test, but where this information is unavailable, sesquioxide levels, clay content, and $\mathrm{pH}$ of the soils can be interpreted to provide an approximate understanding of relative $\mathrm{P}$ retention (van Gool et al., 2005). In addition, the opinions of farmers who cultivate the soils, scientists and advisers who have local knowledge of the potential and behaviour of the soils, can be very valuable in identifying and rating limiting factors. Finally, it is important to calibrate and validate the interpretation of limiting factors by trials designed to test the impact of the limiting factors on crop growth, and the ease with which the limiting factors can be overcome (Bell et al., 2006).

The land to be evaluated can be natural (conversion) forest, abandoned or unproductive lands, or land currently used for agriculture, at a sub-optimal level of management in such a way that the productivity can be improved by changing to more suitable crops using the guidelines of FAO (1976). Land use requirements refer to the pre-requisites for the proposed land use. In this case, we consider requirements for growth of non-rice field crops, as determined by climatic requirements or landscape/ soil factors (Sys et al. 
1993). The utility of the generated data can be significantly enhanced if the taxonomic units are grouped into management units, which can indicate the potential and constraints of an area in terms of its fertility (Prasad, 2000). The fertility capability classification (FCC) system focuses quantitatively on the physical and chemical properties of the soil that are important towards soil fertility management (Sanchez et al., 2003). Therefore, information on physical, chemical and fertility characteristics of soil shall enable the formulation of recommendations for improving specific soil constraints for proper soil management and land use planning (Minh et al., 2006).

Madhya Pradesh in Central India is endowed with vertisols and associated soils along with assured rainfall (700 to $1200 \mathrm{~mm} \mathrm{yr}^{-1}$ ) and is considered the heartland of dryland agriculture. Three fundamental barriers to rainy season cropping in black soil regions: (i) difficulty of soil preparation prior to the monsoon for timely sowing of a rainy season crop; (ii) threat of flooding of the rainy season crop due to heavy rains; and (iii) reduction in available soil moisture for the post rainy season crop (due to high transpiration by the rainy season crop) and consequent reduction in yields. The threats of mid-season drought and other weatherinduced losses at critical plant growth stages contribute to the risks involved in growing a rainy season crop. Consequently, farmers achieve stable but small harvests by sowing a post rainy season crop on known quantities of residual soil moisture. Geographic information system (GIS) offers the capability of integrating spatial and attribute data and subsequent generation of derivative information on pedo-climate to derive spatial and temporal variations in soil water availability parameters (Subba Rao et al., 2001). Seoni is a part of Maikal Hill Zone with 36 per cent of tribal dominated population and 60 per cent of area under kharif cultivation and 39.76 per cent of area under Rabi (CARD, 2010). In order to shape and contextualize, a reconnaissance soil survey in seoni district was carried out with the objective of spatial land use planning for expansion of area under soybean, cotton, wheat and maize using GIS technique so as to improve agricultural productivity and economic returns of tribal farming community in the region

\section{MATERIALS AND METHODS}

Study area: The Seoni district in southern parts of Madhya Pradesh, is located between $21^{\circ} 35^{\prime}$ to $22^{\circ} 58^{\prime} \mathrm{N}$ latitude and $79^{\circ} 12^{\prime}$ to $81^{\circ} 18^{\prime} \mathrm{E}$ longitude (Fig.1). Geologically, the district comprises of Tirodi Biotite Gneiss (TBG) and Supracrustal Sausar Group (SSG) in the south eastern parts while major parts are covered with Deccan Traps with few outcrops of Lamenta, Intertrappean beds, laterite cappings and alluvium ranging in age from Meso-Proterozoic to Recent (Jain et al., 1995). The major land forms are plateaus covering
$51 \%$ of total area followed by hills and ridges $(24 \%$ of total area) and plains (26\% of total area). The climate is subtropical monsoon type with mean annual rainfall of $1384.5 \mathrm{~mm}$ and 69 rainy days in a year. About 85 per cent of the annual rainfall is received during June to September characterizing soil moisture regime as ustic and soil temparature regime as hyperthermic (Velayutham et al., 1999). One third (1/3) of the area in the district is rich in forest wealth specially teak, and bamboo. The major forest belt runs from west to east along the hill ranges of the Satpura and south to north along the foot hills of the Seoni town in southern side. The soils in the region were classified in the subgroups of vertisols, inceptisols, alfisol and entisols. The slightly acid to moderately alkaline, basaltic clay soils have 0.07 to 1.09 per cent of organic carbon and 37.2 to $66.8 \mathrm{cmol} / \mathrm{kg}$ of cation exchange capacity whereas soils on granite are moderately acid to slightly acid with organic carbon more than 1 per cent and base saturation more than 60 per cent (Bobade et al., 2010). The current land use in the district is suboptimal with principal food crops viz., rice (area of 87,700ha and productivity of $1242 \mathrm{~kg} / \mathrm{ha}$ ), wheat (area of $86,700 \mathrm{ha}$ and productivity of $449 \mathrm{~kg} / \mathrm{ha}$ ) and bengal gram (area of $27,600 \mathrm{ha}$ and productivity of $596 \mathrm{~kg} / \mathrm{ha}$ ). The district has net sown area of 364502 hectares where in 281255 ha are in kharif and 179215 hectares under rabi crop. The double cropped area is 95968 ha with irrigation potential of 35.44 per cent (DSR, 2003).

Soil survey and land evaluation: The geopedological approach (Zinck, 1998) was applied for local physiographic analysis. This approach was used to cover larger areas rapidly by establishing relation between geomorphology and soils. The landform map of seoni district was generated as per standard procedures and delineated fifteen landforms on both basaltic rock types of northern plateau and southern granitic formations.. The soil profiles were morphometrically examined (Schoeneberger et al., 2012) and were classified upto subgroup level as per Soil Survey Staff (2006). The methodology for correlation of soil series in the field was done as per the outlines given by Reddy (2006). The soil resource information system was built with a set of files in GIS under a relational data base management system. The spatial soil data were generated by digitizing topographical maps using ARCINFO. The topology of each polygon was builtup and all spatial data had a polyconic projection. Thirty land mapping units described as series associations with their symbols were used for land evaluation exercises. The soil resource information thus generated was used in agricultural use with the application of land capability classification (Klingebiel and Montgomery, 1961), land suitability classification as per FAO frame work (1976) and Sys et al. (1993) and fertility capability classification of Sanchez et al. (1982). The results were integrated with field surveys in GIS for structuring land 


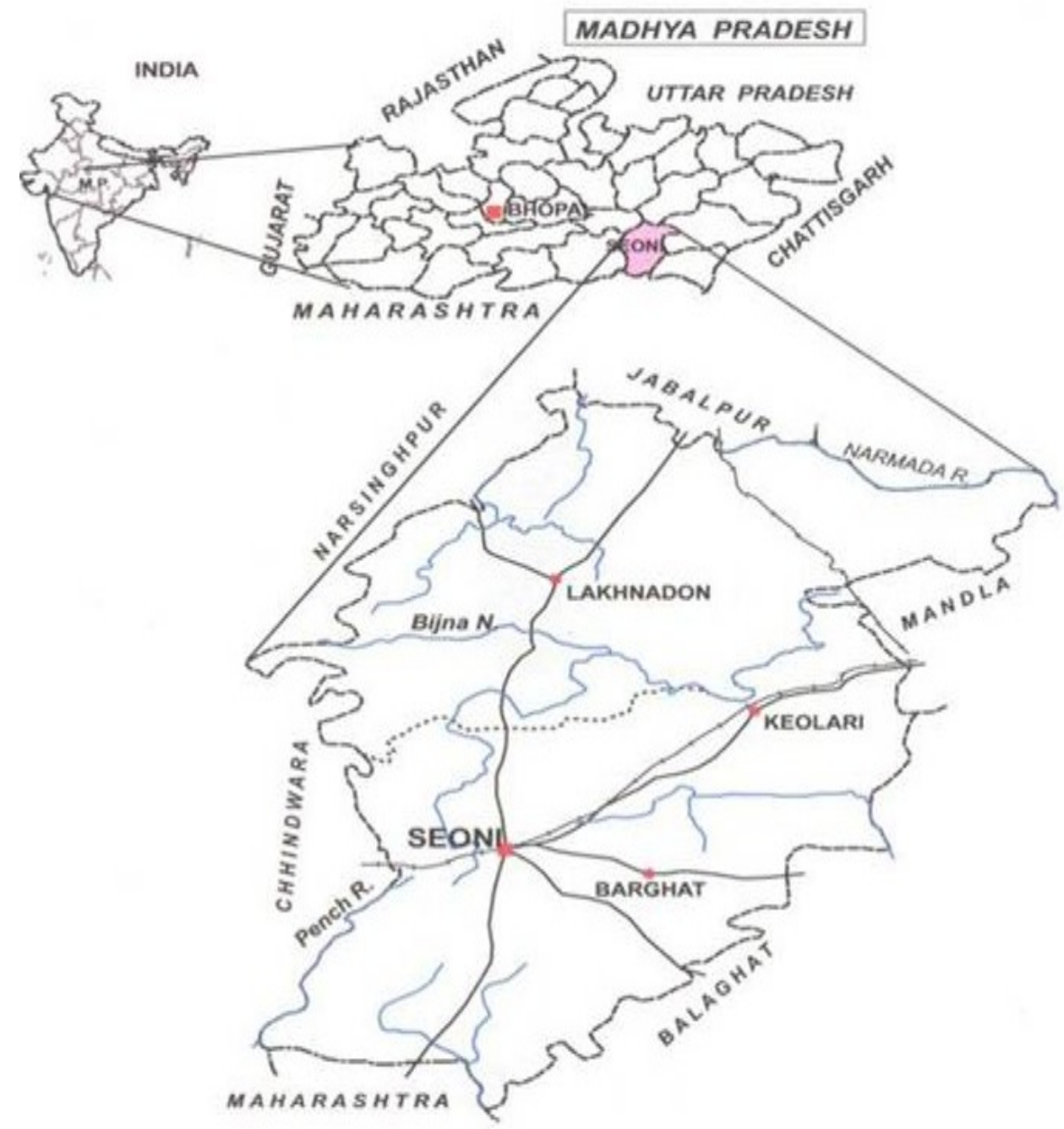

Fig. 1. Location map of Seoni district Madhya Pradesh.

resource data for mapping purpose.

\section{RESULTS}

Landforms and soils: A systematic approach was used to classify landforms on the basis of geological variations, elevational differences and drainage pattern (Subramanyan, 1974). The entire district is divided into fifteen land units such as (i) structural plateaus (2697.92ha), (ii) middle level plateaus (71594.59ha), (iii) narrow interhill basins (81457.45 ha), (iv) structural hills and ridges (152667.92 ha), (vi and vii) upper and lower denudational plateaus (37.22 per cent of total area) and (x, xi, xiii and xv) valleys, broad interhill basins, gently sloping plains and floodplains (8.91 per cent of total area).

The soils on structural plateaus have lithic contact with in $50 \mathrm{~cm}$ with dark brown matrix and clay texture (Table 1). These soils are classified as Lithic Haplustepts (P1- Khamariya series) and Lithic Ustorthents (P2- Dhora series). The soils on middle plateaus $(>500 \mathrm{~m})$ are very deep , moderately to strongly alkaline Kodajhiri series (Typic Haplusterts -
P3) and associated with slightly acid Silghat series (Dystric Haplustepts - P4) having pale brown to dark brownand shallow, dark brown Jamuntola series (Lithic Ustorthents--P5).

The denuded upper basaltic plateaus (19.46 per cent of total area) have very deep Bhimgarh series (Udic Endoaquerts - P8) and light olive brown to dark brown Jamunpani series (Ustic Epiaquerts - P9). The steep escarpments with $>30 \%$ slopes $(2.1$ per cent of total area) supports slightly to moderately alkaline, vertic, light brown to very dark greyish brown Atari series (Vertic Haplustepts - P18) and light olive brown, strongly acid, sandy clay loam textured Massanbarra series (Typic Haplusterts -P19). Likewise, soils on isolated hillocks have moderately deep, well drained, dark brown to dark reddish brown, sandy clay loam textured, slightly acid Lakhanadon series (Typic Haplustepts - P20) and shallow, dark yellowish brown, clay loam Parasia series (Lithic Ustorthents - P17). The occurrence of shallow soils in granitic hilly terrain of Madhya Pradesh were reported (Tamgadge et al., 2000) with constraints of moisture stress, steep slopes 


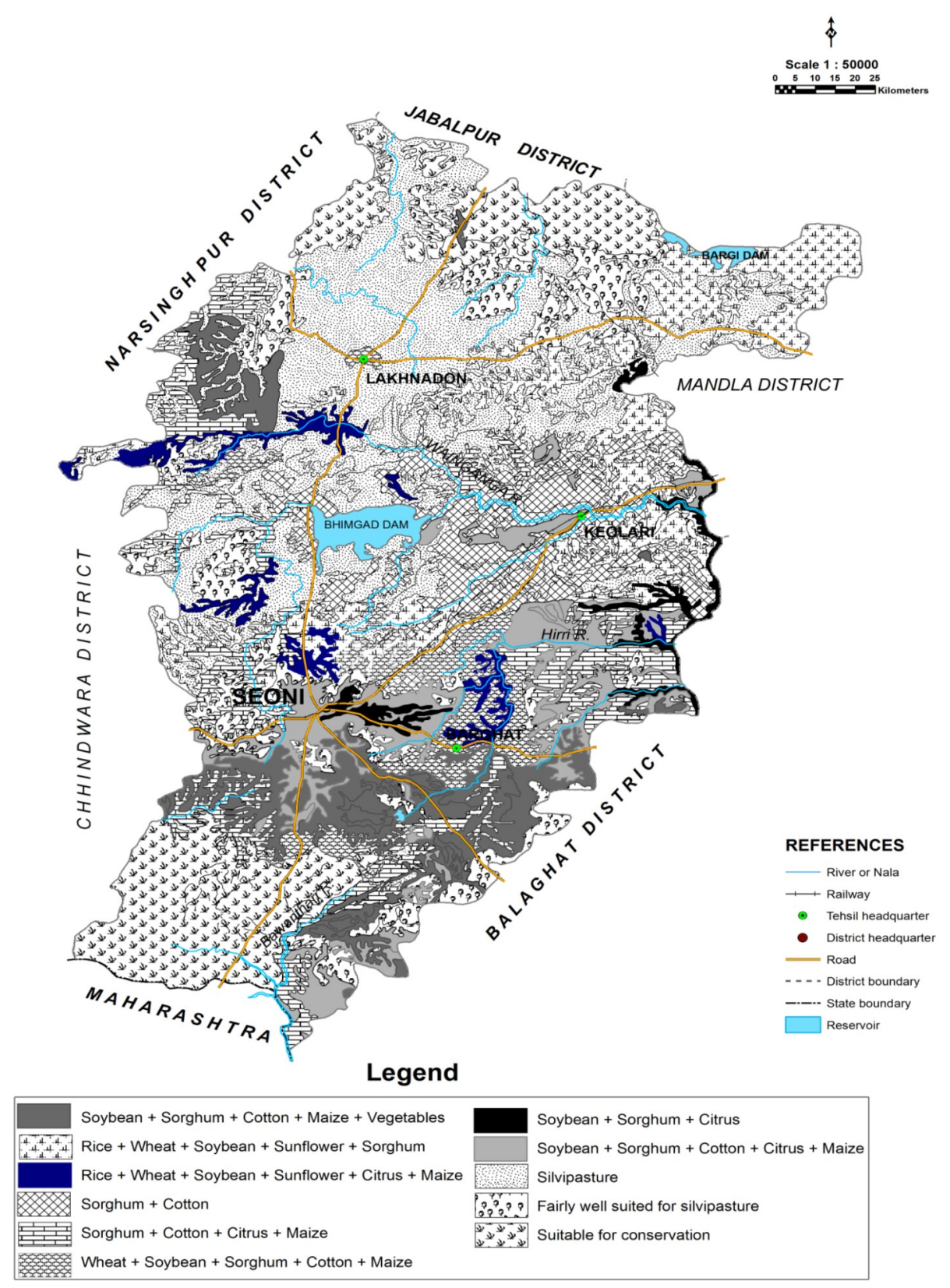

Fig.2 . Land use map of Seoni district, Madhya Pradesh.

and shallow depth that cannot be rectified easily by technology (Eswaran et al., 2000). The shallow clay soils are subjected to erosion on steeper slopes (Mermut et al., 1983) and have hard and compact basaltic bed rock, which makes them unsuitable for agriculture (Pofali et al., 1995). The southern lowlands of hills and ridges covering $7.5 \%$ of TGA have loamy sand to sandy loam textured soils, mostly covered by teak forest and support the tiger habitat in the Pench reserve forest area. The Lungasa series (Ustic Endoaquerts - P26) in valleys are slightly to moderately alkaline with prominent intersecting slickensides and clay content more than 60 per cent but differ in matrix of light olive brown to very dark grey where as soils on gently sloping plains and interhill basins are deep, moderately acid, loamy sand textured (clay less than 15\%, Sagar series - P29) and have light yellowish brown to dark yellowish brown B horizons ( Rukhad series - P28). These soil series are cultivated for paddy and soybean and classified as Typic Haplustepts

Land use assessment: The approach by each land evaluation systems of soil differs and needs a critical study of land characteristics and their range of values to be reviewed in view of land performance at local level (Dent and Young, 1980 and Adeyanju and Fasina, 2007). The land use alternatives proposed using soil resource data with land use interpretations made by three land evaluations systems (Table 2). This region often experiences crop failures and recurring of famine 
Table 1. Description of landforms and soils in Seoni district, Madhya Pradesh.

\begin{tabular}{|c|c|c|c|c|c|c|}
\hline \multirow[t]{3}{*}{ Land forms } & \multirow{3}{*}{$\begin{array}{l}\text { Dominant soil series/*symbol/ } \\
\text { /taxonomy }\end{array}$} & \multicolumn{4}{|c|}{ Soil morphology } & \multirow{3}{*}{$\begin{array}{l}\text { Area } \\
\text { ha/ (per } \\
\text { cent) }\end{array}$} \\
\hline & & \multicolumn{2}{|l|}{ A horizon } & \multicolumn{2}{|l|}{ B Horizon } & \\
\hline & & Colour & Texture & Colour & Texture & \\
\hline \multirow{2}{*}{$\begin{array}{l}\text { 1.Structural } \\
\text { plateaus. }\end{array}$} & 1.Khamariya( Ky*, Lithic Haplustepts) & $7.5 \mathrm{YR} 3 / 4$ & clay & $7.5 \mathrm{YR} 3 / 3$ & clay & 26451 \\
\hline & 2.Dhora (Dh,Lithic Ustorthents) & $7.5 \mathrm{YR} 3 / 3$ & clay & - & - & $(3.02)$ \\
\hline \multirow{4}{*}{$\begin{array}{l}\text { 2.Middle level } \\
\text { plateaus }\end{array}$} & 3.Kodajhiri (Ko, Typic Haplusterts) & $2.5 \mathrm{Y} 4 / 2$ & clay & $2.5 \mathrm{Y} 3 / 2$ & clay & 69688 \\
\hline & 4.Silghat (Si, DystricHaplustepts) & 10YR5/2 & $\begin{array}{l}\text { sandy clay } \\
\text { loam }\end{array}$ & $7.5 \mathrm{YR} 3 / 2$ & $\begin{array}{l}\text { sandy } \\
\text { loam }\end{array}$ & $(7.96)$ \\
\hline & 5.Jamuntola(Jm, Lithic & $10 \mathrm{YR} 3 / 3$ & Sandy loam & - & - & \\
\hline & Ustorthents) & & & & & \\
\hline \multirow[t]{2}{*}{$\begin{array}{l}\text { 3.Undulating } \\
\text { plateaus }\end{array}$} & 6.Chunamati(Ch, Typic Haplustalfs) & $7.5 \mathrm{YR} 3 / 2$ & clay & $7.5 \mathrm{YR} 3 / 2$ & clay & $\begin{array}{l}61632 \\
(7.04)\end{array}$ \\
\hline & 7.Gorakhpur(Go, Lithic Haplustepts) & $2.5 \mathrm{Y} 3 / 1$ & clay & $2.5 \mathrm{Y} 23 / 1$ & clay & \\
\hline \multirow{8}{*}{$\begin{array}{l}\text { 4.Upper } \\
\text { denudationaa } \\
\text { plateaus } \\
\text { 5.Lower denu- } \\
\text { dational } \\
\text { plateaus }\end{array}$} & 8.Bhimgarh( Bg, Ustic Endoaquerts) & $2.5 \mathrm{Y} 3 / 2$ & clay & $2.5 \mathrm{Y} 3 / 2$ & clay & 155239 \\
\hline & 9.Jamunpani (Jp, Ustic Epiaquerts) & $2.5 \mathrm{Y} 4 / 3$ & clay & $2.5 \mathrm{Y} 3 / 2$ & clay & $(17.74)$ \\
\hline & 10.Tarali( Ta, Typic Haplusterts) & $10 Y R 3 / 3$ & clay & $10 Y R 3 / 3$ & clay & \\
\hline & 11.Chhui(Cu,Typic Epiaquepts) & $2.5 \mathrm{Y} 4 / 2$ & clay & $2.5 \mathrm{Y} 3 / 1$ & $\begin{array}{l}\text { sandy } \\
\text { clay }\end{array}$ & $\begin{array}{l}131745 \\
(15.05)\end{array}$ \\
\hline & 12.Dhenka(Dk, Ustic Epiaquerts) & $2.5 \mathrm{Y} 4 / 2$ & clay & $2.5 \mathrm{Y} 3 / 1$ & clay & \\
\hline & 13.Kharsaru (Kh, Ustic Epiaquerts) & $2.5 \mathrm{Y} 3 / 2$ & clay & - & - & \\
\hline & 14.Khawasa (Kw,Typic Haplustepts) & $10 \mathrm{YR} 4 / 4$ & sandy loam & $10 \mathrm{YR} 4 / 4$ & $\begin{array}{l}\text { sandy } \\
\text { loam }\end{array}$ & \\
\hline & 15. Pratappur (Pt, Udic Haplustalfs) & $10 Y R 3 / 2$ & clay & - & - & \\
\hline \multirow[t]{2}{*}{$\begin{array}{l}\text { 6.Structural } \\
\text { hills and ridges }\end{array}$} & 16.Kanera (Kn,Lithic Ustorthents) & $7.5 \mathrm{YR} 3 / 4$ & $\begin{array}{l}\text { sandy clay } \\
\text { loam }\end{array}$ & - & - & $\begin{array}{l}178853 \\
(20.43)\end{array}$ \\
\hline & 17.Parasia (Pa, Lithic Ustorthents & $5 \mathrm{YR} 4 / 3$ & $\begin{array}{l}\text { sandy clay } \\
\text { loam }\end{array}$ & - & - & \\
\hline \multirow[t]{2}{*}{$\begin{array}{l}\text { 7.Denudationale } \\
\text { scarpments }\end{array}$} & 18.Atari( At, Vertic Haplustepts) & $2.5 Y 5 / 3$ & clay & $\begin{array}{l}2.5 \mathrm{Y} 4 / 3 \\
3 / 2\end{array}$ & clay & $\begin{array}{l}18820 \\
(2.15)\end{array}$ \\
\hline & 19.Masanbarra(Ma,Typic Haplustepts) & $10 \mathrm{YR} 3 / 2$ & sandy loam & $10 \mathrm{YR} 4 / 2$ & $\begin{array}{l}\text { sandy } \\
\text { loam }\end{array}$ & \\
\hline \multirow[t]{2}{*}{$\begin{array}{l}\text { 8.Isolated } \\
\text { hillocks }\end{array}$} & 20.Lakhanadon(Lk, Typic Haplustepts) & $7.5 \mathrm{YR} 3 / 2$ & $\begin{array}{l}\text { sandy clay } \\
\text { loam }\end{array}$ & 7.5YR $3 / 2$ & $\begin{array}{l}\text { sandy } \\
\text { clay }\end{array}$ & $\begin{array}{l}6188 \\
(0.71 \%)\end{array}$ \\
\hline & 21.Sukla (Sk, Typic Ustorthents) & $10 \mathrm{YR} 4 / 4$ & clay loam & - & - & \\
\hline 9.Ridges & 22.Pipariya(Pr, Lithic Haplustepts) & $2.5 \mathrm{Y} 4 / 2$ & clay loam & $2.5 \mathrm{Y} 5 / 2$ & $\begin{array}{l}\text { clay } \\
\text { loam }\end{array}$ & $\begin{array}{l}3731 \\
(0.43)\end{array}$ \\
\hline \multirow[t]{2}{*}{$\begin{array}{l}\text { 10.Rolling } \\
\text { pediplains }\end{array}$} & 23.Arandiya (Ar, Udic Haplustalf) & $10 \mathrm{YR} 5 / 4$ & Sandy loam & $10 \mathrm{YR} 4 / 4$ & $\begin{array}{l}\text { sandy } \\
\text { clay }\end{array}$ & $\begin{array}{l}58071 \\
(6.64)\end{array}$ \\
\hline & 24.Gondatola(Gi, Typic Rhodustalfs) & $2.5 \mathrm{YR} 3 / 4$ & Clay & - & - & \\
\hline \multirow{3}{*}{$\begin{array}{l}\text { 11.Narrow inter } \\
\text { hill basins } \\
\text { 12.Valleys }\end{array}$} & 25.Nadora(Nd-Typic Haplusterts) & $2.5 \mathrm{YR} 3 / 4$ & Clay & - & - & $\begin{array}{l}84608 \\
(9.67)\end{array}$ \\
\hline & 26.Lungsa(Lu, Ustic Endoaquerts) & $2.5 \mathrm{Y} 4 / 2$ & Clay & $2.5 \mathrm{Y} 3 / 1$ & clay & $\begin{array}{l}14327 \\
(1.64)\end{array}$ \\
\hline & 27.Paddikona(Pd, Typic Haplusterts) & $10 \mathrm{YR} 2 / 2$ & Clay & $10 \mathrm{YR} 2 / 2$ & clay & \\
\hline \multirow[t]{2}{*}{$\begin{array}{l}\text { 13.Broad } \\
\text { interhill basins }\end{array}$} & 28.Rukhad(Rk, TypicHaplustepts) & $10 \mathrm{YR} 6 / 4$ & loamy sand & $10 \mathrm{YR} 5 / 4$ & $\begin{array}{l}\text { loamy } \\
\text { sand }\end{array}$ & $\begin{array}{l}2451 \\
(0.28)\end{array}$ \\
\hline & 29.Sagar(Sa, Typic Haplustepts) & $10 \mathrm{YR} 3 / 2$ & Clay & $10 \mathrm{YR} 3 / 2$ & clay & \\
\hline $\begin{array}{l}\text { 14.Gently } \\
\text { sloping } \\
\text { floodplains }\end{array}$ & 30.Bisapur(Bs, Typic Haplustepts) & $7.5 \mathrm{YR} 3 / 2$ & sandy loam & $7.5 \mathrm{YR} 3 / 4$ & $\begin{array}{l}\text { sandy } \\
\text { loam }\end{array}$ & $\begin{array}{l}63668 \\
(7.27)\end{array}$ \\
\hline
\end{tabular}

is common. This district is a priority area for improved crop planning and agricultural development. Soil survey data base could be used for land use assessment to enhance land allocation for economically viable crops and to address soil fertility constraints and management problems in areas of low productivity. The land use assessment is made using land capability classification for delineation of arable lands, and then arable lands are evaluated for suitability of rainfed crops considering local crop calendar/ probability of onset of monsoon and fertility capability of arable units with NPK status of soils.

Land capability assessment: Land capability primarily refers to the potential of land to sustain a number of predefined land uses to arable crops, pasture, and woodland and recreation/wild life. Land capability classes generally used to make land use assessments, determine erodible areas and review land use potentials. The soil map with thirty mapping units (series associations) is used to derive land use map. The symbols of series in each mapping unit designed are presented in table 1 . The northern plateaus, covering $11.6 \%$ of total 
Table 2. Soil -site suitability and fertility of soil mapping units for crops in Seoni district, Madya Pradesh

\begin{tabular}{|c|c|c|c|c|c|c|c|c|}
\hline \multirow[t]{2}{*}{ S.N. } & \multirow{2}{*}{$\begin{array}{l}\text { Land suitability for } \\
\text { crops }\end{array}$} & \multirow[t]{2}{*}{ SMU } & \multirow[t]{2}{*}{ LCC } & \multirow[t]{2}{*}{ FCCunits } & \multicolumn{3}{|c|}{ Available (Rating) } & \multirow{2}{*}{$\begin{array}{l}\text { Area } \\
(\mathrm{Ha}) /(\%)\end{array}$} \\
\hline & & & & & $\mathbf{N}$ & $\mathbf{P}$ & $\mathbf{K}$ & \\
\hline \multirow[t]{3}{*}{1} & Soybean-Sorghum- & Sk-Jm-Rk(25), & IVes & CCvdb & $\mathrm{L}$ & $\mathrm{L} / \mathrm{H}$ & $\mathrm{M} / \mathrm{H}$ & $63668(7.27)$ \\
\hline & Cotton-Maize- & Kw-Sk-Ta(27), & IIIes-IVes & CCVdki & $\mathrm{L}$ & $\mathrm{L}$ & $\mathrm{L} / \mathrm{M}$ & $53071 /(6.06)$ \\
\hline & Vegetables & Ta-Ko-Jm(28) & IIIw-IVws & $\mathrm{CCdb} / \mathrm{LRd}$ & $\mathrm{L} / \mathrm{M}$ & $\mathrm{L}$ & $\mathrm{L} / \mathrm{H}$ & $\begin{array}{l}5256 /(0.60) \\
121995 / \\
(13.93)\end{array}$ \\
\hline 2 & $\begin{array}{l}\text { Rice-Wheat-Soybean- } \\
\text { Sunflower-Sorghum }\end{array}$ & Sa-Pd-Ky-Pa(3) & IIIw-IIw & CCRdv & $\mathrm{L}$ & $\mathrm{L}$ & M & $88508 /(10.11)$ \\
\hline \multirow[t]{4}{*}{3} & $\begin{array}{l}\text { Rice-Wheat-Soybean- } \\
\text { Citrus-Maize -Sunflower }\end{array}$ & Go-Sa-Pd(9), & IIw-IIIes & $\begin{array}{l}\text { CRdv/ } \\
\text { CCvdb }\end{array}$ & $\mathrm{L}$ & $\mathrm{L} / \mathrm{H}$ & $\mathrm{M} / \mathrm{H}$ & $10598 /(1.22)$ \\
\hline & & $\mathrm{Bg}-\mathrm{Ky}-\mathrm{At}(16)$ & IVsw-IIIws & CCRdv & $\mathrm{L}$ & $\mathrm{L}$ & $\mathrm{M} / \mathrm{H}$ & $3731 /(0.43)$ \\
\hline & & Sa-At-Lu(19) & IVws-IIIw & $\begin{array}{l}\text { CCVdik/ } \\
\text { CCdi }\end{array}$ & $\mathrm{L}$ & $\mathrm{L}$ & M & $5680 /(0.65)$ \\
\hline & & & & & & & & $20009 /(2.3)$ \\
\hline \multirow[t]{3}{*}{4} & Sorghum-Cotton & Dk-Pd-Kh(13), & IIw-IIIws & CCdi & $\mathrm{L}$ & $\mathrm{L}$ & $\mathrm{M} / \mathrm{H}$ & $46172 /(5.28)$ \\
\hline & & $\begin{array}{l}\text { Kh-Jp-Ch-Pc } \\
(15),\end{array}$ & IIIws-Ivw & $\begin{array}{l}\mathrm{CCvdb} / \\
\mathrm{CCdk}\end{array}$ & $\mathrm{L}$ & $\mathrm{L}$ & $\mathrm{M} / \mathrm{H}$ & $15852 /(1.81)$ \\
\hline & & Kh-Go-Lk(17) & IIIws-IIIes & $\mathrm{CRdv} / \mathrm{LLdk}$ & $\mathrm{L}$ & $\mathrm{L}$ & M & $\begin{array}{l}16617 /(1.89) \\
78641 /(8.98)\end{array}$ \\
\hline \multirow[t]{3}{*}{5} & Sorghum-Cotton-Citrus- & At-Pa-Bg(4), & IIIs-IVws & $\mathrm{CCvdb}$ & $\mathrm{L}$ & $\mathrm{L}$ & $\mathrm{M} / \mathrm{H}$ & $23143 /(2.64)$ \\
\hline & Maize & At-Lu-Kh(11), & IVws-IIIws & CCdi & $\mathrm{L}$ & $\mathrm{L}$ & $\mathrm{M} / \mathrm{H}$ & $6358 /(0.73)$ \\
\hline & & Kw-Lu-Lk(29) & IIIes-IVws & CCdi & $\mathrm{L}$ & $\mathrm{L} / \mathrm{M}$ & $\mathrm{L} / \mathrm{M}$ & $\begin{array}{l}52139 /(5.96) \\
81640 /(9.33)\end{array}$ \\
\hline \multirow[t]{5}{*}{6} & Wheat-Soybean- & $\mathrm{Nd}-\mathrm{Sa}-\mathrm{Dh}(6)$ & IIIw & CRdik & $\mathrm{L} / \mathrm{M}$ & $\mathrm{L}$ & $\mathrm{L} / \mathrm{H}$ & $6188(0.71)$ \\
\hline & Sorghum-Cotton-Maize & $\operatorname{Pr}-\mathrm{Sa}-\mathrm{Jb}(8)$ & IIIw & $\mathrm{CCvdb}$ & $\mathrm{L}$ & $\mathrm{L}$ & $\mathrm{M} / \mathrm{H}$ & $2451(0.28)$ \\
\hline & & $\mathrm{Si}-\mathrm{At}-\mathrm{Cu}(12)$ & IVws-IIIws & CCvdki & $\mathrm{L}$ & $\mathrm{L}$ & M & $10766 /(1.23)$ \\
\hline & & $\begin{array}{l}\text { Jm-Gl-Kh-Rk } \\
(23)\end{array}$ & Ives-IIIes & CCdki/LLdk & $\mathrm{L}$ & M & M & $16447 /(1.88)$ \\
\hline & & & & & & & & $35852 /(4.1)$ \\
\hline 7 & $\begin{array}{l}\text { Soybean-Sorghum- } \\
\text { Citrus }\end{array}$ & $\mathrm{Sa}-\mathrm{Bg}-\mathrm{Dh}(14)$ & IIIw & CRdik & $\mathrm{L}$ & $\mathrm{L}$ & $\mathrm{M} / \mathrm{H}$ & $12462 /(1.42)$ \\
\hline \multirow[t]{4}{*}{8} & $\begin{array}{l}\text { Soybean-Sorghum- } \\
\text { Cotton-Citrus-Maize }\end{array}$ & $\begin{array}{l}\text { Ar-Kh-Bg-Nd } \\
(10),\end{array}$ & IIIws & CCdi/CCvdb & $\mathrm{L}$ & $\mathrm{L} / \mathrm{H}$ & $\mathrm{L} / \mathrm{H}$ & $32724 /(3.24)$ \\
\hline & & Ko-Kw-Sk(21)- & IVes-IIIes & LLdk/LRd & $\mathrm{L} / \mathrm{M}$ & $\mathrm{L}$ & $\mathrm{L} / \mathrm{H}$ & $24330 /(2.78)$ \\
\hline & & $\begin{array}{l}\text { Pt-Gl-Kw-Rk } \\
(24)\end{array}$ & & CCdki/SSdki & $\mathrm{L} / \mathrm{M}$ & $\mathrm{L} / \mathrm{M}$ & $\mathrm{L} / \mathrm{H}$ & $12547 /(1.43)$ \\
\hline & & & & & & & & $69601 /(7.45)$ \\
\hline \multirow[t]{5}{*}{9} & Forestry and Grazing & P-Pd-Ky(1), & Ves-VIIes & CCRdv & $\mathrm{L}$ & $\mathrm{L}$ & M & $41032 /(4.69)$ \\
\hline & & $\operatorname{Pa}-\operatorname{Pr}-\mathrm{Ky}(2)$ & V-VIIes & $\mathrm{LRd} / \mathrm{CCrdv}$ & $\mathrm{L}$ & $\mathrm{L}$ & M & $98511 /(11.26)$ \\
\hline & & $\begin{array}{l}\text { Kt-At-Pc-Roc } \\
(5)\end{array}$ & Ves-VIIes & $\begin{array}{l}\text { CCvdik/ } \\
\text { CCvdb }\end{array}$ & $\mathrm{L}$ & $\mathrm{L}$ & M & $71467 /(8.16)$ \\
\hline & & $\begin{array}{l}\text { Kn-Bs-Jm-Roc } \\
(26)\end{array}$ & IVes-Vies & SSdki & $\mathrm{L}$ & M & M & $10598 /(1.21)$ \\
\hline & & & & & & & & $\begin{array}{l}221608 / \\
(25.32)\end{array}$ \\
\hline \multirow[t]{3}{*}{10} & Fairly well suited for & Lk-Pr-Sa-Lu(7), & VI-VIIes & $\mathrm{LRd} / \mathrm{CCvdb}$ & $\mathrm{L}$ & $\mathrm{L} / \mathrm{M}$ & $\mathrm{L} / \mathrm{M}$ & $25053 /(2.86)$ \\
\hline & Forestry and Grazing & $\begin{array}{l}\text { Pa-Ma-Ky-Roc } \\
\text { (18), }\end{array}$ & VIIes-Ves & $\begin{array}{l}\text { LLdk/ } \\
\text { CCRdv }\end{array}$ & $\mathrm{L}$ & $\mathrm{L}$ & $\mathrm{L} / \mathrm{M}$ & $20600 /(2.35)$ \\
\hline & & Sk-Jm-Bs-(20) & VIIes-Vies & SSdki & & & & $\begin{array}{l}47618 /(5.44) \\
93271 /(10.65)\end{array}$ \\
\hline \multirow[t]{3}{*}{11} & Suitable for Wild Life & $\begin{array}{l}\text { Dh-Sk-Kw-Nd } \\
(22) \text {, }\end{array}$ & VIIIes & $\mathrm{LRd} / \mathrm{LLdk}$ & $\mathrm{L} / \mathrm{M}$ & $\mathrm{L}$ & $\mathrm{L} / \mathrm{H}$ & $43237 /(4.94)$ \\
\hline & & Dh-Sk-Pt(30) & $\begin{array}{l}\text { VIIIes- } \\
\text { VIIes }\end{array}$ & $\mathrm{LRd} / \mathrm{CCvdb}$ & $\mathrm{L}$ & $\mathrm{L} / \mathrm{M}$ & $\mathrm{L} / \mathrm{M}$ & $8647 /(0.99)$ \\
\hline & & & & & & & & $51884 /(5.93)$ \\
\hline
\end{tabular}

geographical area, have dominant soil associations of Parasia (Pa - P17) - Pipariya (Pr - P22) - Khamariya $(\mathrm{Ky}-\mathrm{P} 1)$. These soils are well drained, sandy clay loam textured and were cultivated for sorghum and red gram whereas in lower denudational plateaus, these soils were used for cultivation of paddy and soybean.
The soils over structural hills and severely eroded plateaus are very shallow $(<10 \mathrm{~cm})$ to shallow $(25$ $50 \mathrm{~cm})$, somewhat excessively drained and sandy clay loam to clay loam were used for millets and kondon kutki (a staple food in the form of Pej). The southern granitic lowlands under forest $(14.7 \%$ of total area) 
have well drained, shallow to moderately deep soil series viz., Kanera (P16), Khawasa (P14), Jamuntola (P5), Sukla (P21), Dhora (P2) and Prattapur(P15).

The striking land features that determine capability class of VI to VII in plateaus and hills are steep slopes with outcroppings of boulders impose difficulty to work with machinery and costly to manage for crops. Most of the lands in northern Lakhanadon plateaus and upper Wainganga valleys are cleared and exposed with stony and gravelly shallow red and black soils capable of supporting grazing at low carrying capacity. The land capability class III includes six mapping units such as (i) Sagar - Paddikona - Khamariya - Parasia (3), (ii) Atari - Parasia - Bhimgarh (4), (iii) NadoraSagar - Dhora (6), (iv) Pipariya - Sagar - Jamunpani (8), (v) Sagar - Bhimgarh - Dhora (14) and (vi) Kharsaru - Jamunpani - Chunamati - Parasia (15) occurring on gently to moderately sloping lands with black or mixed red and black soil regions. The class III units cover forty one per cent of area with erosion and shallowness of soils on steep slopes. The class IV soils mostly concentrated in the northern plateaus cover 15.1 per cent with erosion and root zone limitations .and

Land suitability: The frame work for land evaluation (FAO, 1976) received conceptual inputs from the reconnaissance soil survey of Seoni district. Most applications are qualitative, matching degrees of limitation or quality of the land with corresponding requirements of specific kinds of land use. The 11 land use suitable units (Fig. 3) based on soil -site suitability analysis showed that 55.4 per cent of area is arable in the Seoni district. Within the arable units, rice - wheat cropping system is suitable in 2.17 per cent of total area covering four soil mapping units (Sagar - Paddikona - Khamariya - Parasia (3), Gorakhpur - Sagar Paddikona (9), Bhimgarh - Khamariya - Atari (16) and Sagar - Atari - Lungsa (19). The suitability analysis further revealed that 24 per cent of land is suitable for sorghum - soybean, 15.29 per cent for sorghum - cotton and 24 per cent of total arable land for citrus in the district. The nonarable portion (44.6 per cent) of total land is evaluated for forestry and wild life. Thirty seven per cent of land is suitable for forestry and grazing, and remaining 6.8 per cent is suitable for wild life and details of land units is given as Table 2 . The non arable portion is mostly concentrated in upper ridges of Lakhanadon plateau and the cultivated area in gently sloping plains and lower pediments in north-eastern and south- central parts of the district.

Fertility capability: A total of eight fertility capability units were defined in the combinations of type, substrata type and modifiers (Sanchez et al., 1982). The five FCC units in basaltic terrain having clay top soils and hard root restricting substrata under ustic soil moisture regime is defined as CRdv. The modifiers of low $\mathrm{K}$ reserves, high $\mathrm{P}$ fixation and presence of 15-35 per cent gravel by volume is defined as CRbik and the severe top swelling and shrinking as CRdv. The vertic characteristics, high $\mathrm{P}$ fixation and low $\mathrm{K}$ reserves are defined as CCVdik but with high swell shrink potential and deficiencies of P, Fe and $\mathrm{Zn}$ as CCvdb (Table 2). The basaltic clay soils are generally low in $\mathrm{N}$ but high in available phosphorus and potassium and medium in Zn levels.

The soils in granitic landforms with loamy top soil and hard root restricting substrata (LRd) have low ability to retain nutrients like $\mathrm{K}, \mathrm{Ca}$ and $\mathrm{Mg}$. The sandy top soils with low water holding capacity, low K supply and 1535 per cent gravels are defined as SSbk. The soils on granitic land forms have low N, P, K and Zn (Table 2). The extent and spatial pattern of each fertility capability units is in ascending order of CCvdb (38.71\%) > CCvdik $(18.7 \%)>\operatorname{LLdh}(16.55 \%)>\operatorname{CCRdv}(9.68 \%)$ and $>$ CRidh $(6.12 \%)$. The soil fertility analysis shows that $41 \%$ of soils in northern Lakhanadon plateau are low in available nitrogen, phosphorus and medium potassium where as soils in southern lowlands have low nitrogen, low or high phosphorus and medium to high available potassium contents and the soils in upper Wainganga valley have low nitrogen, phosphorus and medium to high available potassium contents.

\section{DISCUSSION}

Seoni, being a part of Satpura-Maikal region with an average elevation of $300 \mathrm{~m}$, is drained by Wainganga and Pench rivers. This region is a drought hit area with mean annual rainfall of $1474 \mathrm{~mm}$ with mean daily maximum temperature of $39.9^{\circ} \mathrm{C}$ and minimum mean daily temperature of $24.8^{\circ} \mathrm{C}$. The high temperature during the end of the dry season (March to May) when coincide with sensitive phases of soybean may be a limiting factor for crop production (Ahn and Shanmugasundram, 1989; Sys et al., 1993). Using the information of the soil geographical database at 1:50000 scale is beneficial in term of assessing the inventory of soil resources, managing their agricultural potential productivity and problems, and directing the attention towards the fragile agro ecosystem. The soil classification accompanied by a series of landscape and soil indicators are used to characterize agricultural potential with the limitations of stones and gravels content, soil depth, salinity, erosion status, flooding hazards. Such detailed and comprehensive information allow for the integration and evaluation of the economic situation and crop optimal distribution and yields. Concerning the soil mapping units (SMU) of the the region, the main problem of the soil cover remains water erosion in connection with soil texture, presence of impermeable layer, vegetation cover and climate. Moreover, the actual erosion rate could be assessed based on the data provided in the directory on dominant and secondary parent material, soil types and the percentage of the area of each soil typological unit. Defining the areas subject to erosion- hazards helps elaborating preventive and remediation measures and scenarios for more sustainable land uses. The land capability map, produced by combining several layers related to the geomorphology and soil characteristics (depth, texture, 
organic matter content, drainage and erosion rate), showed three main categories of lands such as . Class II soils covering $6.8 \%$ of total area have moderate limitations for the choice of crops and require moderate conservation practices. This capability class has two soil mapping units such as Go-Sa-Pd (10948 ha, $1.25 \%$ ) and Dk-Pd-Kh (48257ha, 5.55\%) spreading over the central and southern parts of Seoni district where agriculture is practiced on plateau surfaces and hill slopes less than $8 \%$ with traditional soil conservation practice. Class III soils covering $20.23 \%$ of area have severe limitations for the choice of crops to be grown and require special conservation practices. The arable unit has 7 soil units occurring on moderately sloping with surface rockiness at few places posing limiting factors for the development of sustainable agriculture. However, removal of boulders and construction of terraces on slopes transform these lands into good agricultural lands . Overgrazing and water erosion are main two causes of land degradation in the area. The class IV units cover $31.22 \%$ of area with marginal soils on steep that can be used safely for forestry, recreation, urban expansion and wildlife .

Land qualities that relate to tillage are particularly significant in Seoni where draft animals are still used to prepare land for most cropping. When dry, these vertisols and vertic intergrades of Seoni (Table -1, soil series namely Kodajhiri (P3), Jamunpani (P9), Dhenka (P12), Kharsaru (P13), Khawasa (P14), Lakhanadon (P20), Nadora (P25), Lungsa (P26), Paddikona (P27) and Sagar (P29) ), especially in the Lakhanadon plateau, valley of Sagar and Hirvi, upper and lower Wainganga valleys have limitation high strength and hard setting for tillage by draft animals and excessive wetness and low load bearing capacity for tractor tillage (White et al., 1997). The erratic rainfall over most of Seoni district creates constraints for crop emergence. Intense rainfall in southern lowland coupled with low soil structural stability (Khasawa (P14), Sukla - P21, Rukhad - P28 and Bisapur - P30, series) causes slaking of surface soils and making them prone to form hard crusts as they dry. Crusting will impede seedling emergence. Crusting probably relates to low organic matter levels and lack of retention of crop residues,. Poor soil structure as a constraint to tillage and crop establishment may be a common problem for non-rice crops on paddy fields since soils are repeatedly tilled wet to break down soil structure to improve soil water retention during the rice (Singh et al., 2011). The constraints of intense rainfall and poor soil structure are exacerbated by the use of low quality seed. Farmers commonly reported that soybean seed has to be re-sown if moisture conditions are less than ideal after sowing since the seeds have low vigour and cannot tolerate either excess moisture or drying of the seedbed during emergence (Piara singh, et al., 2002).

Intense rainfall events will often lead to water logging in Sagar (Sa - P29), Paddikona (Pd- P27), Khamariya $(\mathrm{Ky}-\mathrm{P} 1))$ and Parasia (Pa - P17) soils during wet season because the infiltration rate is much less than rainfall rates. This is beneficial for rice cultivation because it contributes to stored water. Rice fields pose an extra water logging risk due to bunding of fields and development of a plough pan at $10-20 \mathrm{~cm}$ depth that limits drainage within the profile. Water supply (drought) is a key limiting factor during the wet season. Hence the water storage capacity of the soil would have a large bearing on the regulation of water availability to crops especially during periods of little or no rainfall (Sohan lal et al., 1994). The depth of soils at different locations varied from $45 \mathrm{~cm}$ at Khamaria (Ky - P1)) to $150 \mathrm{~cm}$ at Nadora $(\mathrm{Nd}-\mathrm{P} 25)$, Bhimgarh (Bg), Jamunpani (Jp - P9), Paddikona (Pd P27) with range of 50 to $200 \mathrm{~mm}$ for the whole soil profile (Aditi Sarkar, 2008). Based on average transpiration rates of 6-8 mm/day (Fukai and Cooper, 1995), farmers' reported that 5 days or more without rain may cause water stress or off $>35 \mathrm{~mm}$ water storage in the top one metre of the profile is considered to be a minimum for soybean based cropping systems in the region whereas greater than $70 \mathrm{~mm}$ soil water storage would allow crops to grow with minimal water stress for 10 days or more. Soybean and maize are less tolerant to drought than sesame, mung bean and peanut (Sys et al., 1993; Bell et al., 2006). Hence low soil water storage is severe constraint for soybean and maize than other crops, and probably explains why farmers tend to grow these crops during wet season. The area under shallow soils with lithic contact within $50 \mathrm{~cm}$ is estimated as $4342.42 \mathrm{~km}^{2}$ (51.23 per cent of total area) where critical thresh hold for soil water is reported to be in the range of $0.8^{\text {th }}$ fraction of available soil water but varies to 0.25 part for deep black soils (Sadras and Miltroy , 1996). The irrigation intervals were reported for deep to shallow black soils varies from 14 to 9 days in basaltic regions of Jayakwadi command area of Maharashtra (Bhaskar, et al., 2010). The influence of precipitation and topography on yield of soybean / cotton is quite contradictory in semiarid regions due to poor drainage in foot slopes during wet season and water deficit in uplands during prolonged seasonal dry spells (Ramkrishna Rao et al., 1986 and Bhaskar, 1997).

Soil nutrient supply through fertilizer application enables nutrient constraints to be overcome. However, fertilizer use remains very low based on surveys in Madhya Pradesh. The basaltic clay soils in Seoni district are low in available nitrogen, phosphorus, potassium and zinc contents whereas granitic soils in southern lowland are low in nitrogen, phosphorus and zinc status (Tamgadge et al., 2008). Of the crops used in the present study, soybean is least likely to tolerate such low P levels (Dierolf et al., 2001). The granitic soils are slightly acid (Dhora-P2) and Parasia -P17) to moderately acid (Sukla - P21, Prattappur - P15 and 
Chunamati - P6) with base saturation more than 60 per cent. It is estimated that sixty one per cent of total area $\left(5151.71 \mathrm{~km}^{2}\right.$ of area) is having low potassium reserves (K status) and thirty two per cent of area $\left(2731.22 \mathrm{~km}^{2}\right)$ with high P fixation problems.

The key land degradation hazard that needs to be assessed in upland soils in the region is erosion potential. Slope angle and slope length in basaltic plateaus are subjected to moderate erosion covering 18.4 per cent of total area $\left(1563.78 \mathrm{~km}^{2}\right)$. Farmers' perceptions of erosion are consistent with observed soil properties and slope of the land. Similar conclusions were reached regarding low erosion risk of upland cotton growing soils on basalt in the Central Highlands of Yavatmal (Bhaskar et al., 2014). Hence it is important that erosion risk can be assessed in land capability classification to ensure that unsustainable land uses for crops are not proposed. On the other hand, the emergence of minimum tillage and stubble retention systems for crop establishment would greatly reduce the erosion hazard.

\section{Conclusion}

The land resource inventory of tribal populated Seoni district of Madhya Pradesh showed that the district is divided into fourteen landform units on various geological formations wherein upper and lower denudational plateaus covered 37 per cent of total area. During field survey, thirty soil series were identified to derive soil map consisting of 30 mapping units as series association. These soil mapping units were used for land use and fertility capability interpretations. The soil-site suitability analysis showed that eleven land use zones were delineated and estimated that 19 per cent of area is suitable for sorghum - cotton systems. The shrink-swell soils in northern plateaus $(38.7 \%$ of total area) has a potential deficiency of phosphorus, potassium and zinc while loamy to sandy soils in southern zone have low water holding capacity, rapid infiltration and low available potassium and zinc status. The soil survey data sets are useful for exchange of soil management information among closely related soils for agrotechnology transfer by soil analogy.

\section{ACKNOWLEDGEMENTS}

Authors express their sincere thanks to Smt. Ujjwala and Ramtek, Technical officer, Cartography section for their help in preparing GIS maps for this manuscript and S.V. Bobade, S.S. Gaikwad, S.G. Anantwar and Smita Patil, Technical officers of Division of Soil Resource Studies for laboratory analysis.

\section{REFERENCES}

Adeyanju, A. and Fasina A.S. (2007). Comparision of three land evaluation systems in evaluating the predictive value of some selected soils in Ado-Ekiti, South West Nigeria. Nigerian Journal of Soil Science, 17: 113-119.

Aditi Sarkar. (2008). Geospatial approach in soil and cli- matic data analysis for agroclimatic suitability assessment of major crops in rainfed agroecosystem . Andhra University. M.Tech. Thesis .

Ahn, C.S. and Shanmugasundram, S. (1989). Mungbean. In: Detecting Mineral Nutrient Deficiencies in Tropical and Temperate Crops. Eds D.L. Plunkett and H.B Sprague. pp. 129-136. Westview Tropical Agriculture Series No. 7.

Bell, R.W., Seng, V.,Schoknecht, N., Hin, S., Vance, W. and White, P.F. (2006). Land capability classification for nonrice crops in soils of the sandy terrain of Tram Kak district, Taeko Province. CARDI Soil and Water Science. Technical Note. 9.1-17.

Bhaskar, B.P. (1997). Soils of Jayakwadi Irrigation Project, Minor-4. Technical Report No.535. NBSS\&LUP Publication. Nagpur, pp.89.

Bhaskar, B.P., Dipak Sarkar, Mandal, C., Bobade, S.V., Gaikwad, M.S., Gaikwad, S.S., Nimkar, S.S. and Bhattacharyya, T. (2014). Reconnaissance soil survey in Yavatmal District, Maharashtra, India. NBSS Publ. No. 1059. NBSS \& LUP., Nagpur.208p.

Bhaskar, B.P., Raja, P., Gajbhiye, K.S., Maji, A.K., Singh, S.R., Anantwar, S.G. and Nimkar, A.M. (2010). Topographic appraisal for irrigation suitability in a part of Jayakwadi command area, Parbhani district, Maharashtra. Journal of the Indian Society of Soil Science. 58 (4):363-370.

Bobade, S.V., Bhaskar, B.P , Gaikwad, M.S., Raja, P., Gaikwad, S.S., Anantwar, S.G., Patil, S.V., Singh, S.R. and Maji, A.K. (2010). A GIS based land use suitability assessment in Seoni district, Madhya Pradesh, India. Tropical Ecology, 51(1): 41-54.

CARD. (2010). Impact assessment of ICDS in Madhya Pradesh. Final report. 2009-2010 submitted by PMPSU (Poverty monitoring and policy support unit).Study supported by DFID (Department for International Development).1-177p.

Dent, F.J. and Young, A. (1980). Soil Survey and Land Evaluation. George Allen and Unum. London. pp.278.

District Statistical Report. (2003). Seoni District, Madhya Pradesh, District Statistical Office, Seoni.

Dierolf T., Fairhurst T., and Mutert E. (2001). Soil Fertility Kit. GTZ-GmbH, FAO, PT Jasa Katom, and PPI and PPIC. Oxford Graphic Printer.

Eswaran, H., Reich, P. and Beinroth, F. (2000). Land resources of South Asia-stresses, quality and population supporting capacity. International Conference on Managing natural resources for Sustainable Agricultural production in the $21^{\text {st }}$ Century, Invited papers. New Delhi, February 14-18. pp.97-109.

Fukai S. \& Cooper M. (1995). Development of droughtresistant cultivars using physiomorphological traits in rice. Field Crops Research 40 :, 67-86

Jain, S.C., Nair, K.K.K. and Yedekar, D.B. (1995). Geology of the Son-Narmada-Tapti Lineament Zone in Central India, Spl. Publ. Geol. Survey India $10: 1-154$.

FAO (1976). A Frame work for land evaluation. Soils Bulletin 3, FAO, Rome, 72pp.

Klingebiel, A.A. and Montgomery, P.H. (1961). Land capability classification. Agri. Handb.210, USDA, Soil conserve. Serv., Washigton, DC.

Kushwaha, S.P.S., Subramanian, S.K., Kameswara Rao, S.V.C., Ramana Murthy, J, Chennaiah, G., Perumal, A. and Beherea, G. (1996). Interfacing remote sensing and GIS methods for sustainable development. International Journal of Remote Sensing, 17: 3055-3069. 
Maji, A.K., Nayak, D.C., Krishna, N.D.R., Srinivas, C.V., Kamble, K., Reddy, G.P.O. and Velayutham, M. (2001). Soil information system of Arunachal Pradesh in a GIS environment for land use planning. International Journal of Applied Earth Observation and Geoinformation, 3: 69-77.

Mermut, A.R., Acton, D.F. and Eilers, W.D. (1983). Estimation of soil erosion and deposition by a landscape analysis Technique on clay soils in Southwestern Saskatchewan. Canadian Journal of Soil Science, 63:727-739.

Minh, V.Q., Tri, L.Q. and Guong, V.T. (2006). Establishing the Suitable Fertility Capability Classification (FCC) System for Intensive Rice Cultivation Areas in the Mekong Delta, Viet Nam in $18^{\text {th }}$ World Congr. Soil Sci., July 9- 15, (2006) at Philadelphia, Pennsylvania, USA.

Piara Singh, Vijaya, D., Srinivas, K., and Wani, S.P. (2002). Potential productivity, yield gap, and water balance of soybean-chickpea sequential system at selected benchmark sites in India. Global Theme 3: Water, Soil, and Agrobiodiversity Management for Ecosystem Health. Report no.1. Patancheru 502 324, Andhra Pradesh, India: International Crops Research Institute for the Semi-Arid Tropics. $52 \mathrm{pp}$.

Pofali, R.M., Gaikwad, S.T. and Swaminanathan, M. (1995). Study of Geomorphic Features in Chandrapur District, Maharashtra. In: Jog, S.R., (Ed.), Indian Geomorphology, Rawat Publications, Jaipur, 2: 221-229.

Prakash, A.K., Muralikrishna, I.V., Mishra, P. K. and Chalam, R.V.R.K. (2007). Deciding alternate land use options in a watershed using GIS. Journal of Irrigation and Drainage Engineering., 133(2): 162-174.

Prasad, J. (2000). Application of fertility capability classification system in soils of a watershed in semi-arid tropics. $J$. Ind. Soc. Soil Sci., 48(2): 329-338.

Rabia, A.H. (2012). A GIS based land suitability assessment for agricultural planning in Kilte Awulaelo district, Ethiopia. The $4^{\text {th }}$ International Congress of ECSSS, EUROSOIL 2012 "soil science for the benefit of mankind and environment", pp: 1257, 2-6 June, Bari, Italy.

Ramkrishna Rao, G., Sondge, V.D. and Bhonsle, S.S (1986).Climatic conditions in Jayakwadi and Purna commands with reference to water management. Agricultural Development in Jayakwadi and Purna Command areas. Marathwada Agricultural University, Parbhani.

Reddy, R.S. (2006). Methodology for Correlation of Soil Series in Soil Survey and Mapping. Agropedology, 6: 111.

Ritung,S., Wahyunto, Agus, F. and Hidayat, H. (2007). Land suitability evaluation with a case map of area of Arch Barat district, Indonesian Soil Research Institute and World Agroforestry Centre. Bogor, Indonesia.

Sadras, V.O. and Milroy, S.P. (1996). Soil water threshold for responses of leaf expansion and gas exchange: A review. Field Crops Research. 47:253-266.

Sanchez, P.A., Couto, W. and Boul, S.W. (1982). The fertility capability soil classification : interpretation, applicability and modification. Geoderma, 27: 283-309.

Sanchez A, Palm CA and Boul WS (2003). Fertility capability soil classification: a tool to help assess soil quality in the tropics. Geoderma., 114: 157-185.

Schoeneberger, P.J., Wysocki, D.A., Benham, E.C. and Soil Survey Staff. (2012). Field book for describing and sampling soils. Version 3.0., Natural Resources Conservation Service, National Soil Survey Center, Lincoln, NE.

Singh, P.K., Rathore, L.S., Singh, K.K. and Athiyaman, B. (2011). Analysis of rainfall variability and characteristics of rainfed rice condition in Eastern India. (eds by Attri, S.D. et al.) Challenges and Opportunities in Agrometeorology. Springer-Verlag, Heidelberg, Berlin, pp.579

Sohan Lal, Deshpande, S.D. and Sehgal, J. (1994). Soil Series of India. NBBS \& LUP, Nagpur.

Soil Survey Staff. (2006). Keys to Soil Taxonomy. United States Department of Agriculture , Natural Resource Conservation Service. Washington, DC.

Subba Rao, A., Rupa, T.R. and Srivastava, S. (2001). Assessing potassium availability in Indian Soils. In: N.S. Pasricha andS.K. Banasal (ed.) Potassium in Indian Agriculture, special publication: Potash Research Institute of India, Gurgaon,Haryana: 125-157.

Subramanyan,V. (1974). A quantitative analysis of two drainage basins around Sagar, M.P. Proc. Indian Natn. Sci. Acad., 40: 76-99.

Sys, C., Van Ranst, E. and Debaveye, J. (1993). Land evaluation. Part 3: Crop requirements. Agricultural publications 7, 3. General Administration of Development Cooperation of Belgium, Brussels. 199p.

Tamgadge, D.B., Gaikwad, S.T., Gajbhiye, K.S. and Gaikwad, M.S. (2000). Soil Landform Relationship of Granite/ Gneissic terrain in Deccan Plateau, Satpura range, Madhya Pradesh. Journal of Indian Society of Soil Science., 48(3) : 567-571.

Tamgadge, D.B., Bhaskar, B.P., Singh, S.R., Bobade, S.V., Gaikwad, M.S. and Gaikwad, S.S. (2008). Soil resource inventory for land use planning in Seoni district, Madhya Pradesh. Technical report No.1020. NBSS \& LUP., Nagpur. 154p.

Van gool, D., Tille, P. and Moore, G. (2005). Land evaluation standards for land resource mapping. Resource management Technical Report.298. $3^{\text {rd }}$ edition. Department of Agriculture. Government of Western Australia. 131p.

Velayutham, M., Mandal, D.K., Mandal, C. and Sehgal, J.L. (1999). Agroecological subregions in India for planning and Development. Publ.No.35, NBSS \& LUP, Nagpur.

White, P.F., Oberthur, T. and Pheav, S. (1997). The Soils Used for Rice Production in Cambodia. A Manual for their Identification and Management. International Rice Research Institute: Manila.

Zinck, J.A. (1998). Physiography and soils. Lecture notes for soil students. Soil Science Division. Soil Survey Courses Subject Matter, K-5, ITC, Enchede, The Netherlands. 